\title{
PROFESSIONAL COMMUNICATION: FROM FRAME SEMATICS TO LEARNING ENVIRONMENT
}

\section{Dunaievska O. V.}

\section{INRODUCTION}

"Wise men speak because they have something to say; fools - because they have to say something" (Plato). A bit of wisdom from Plato turns to be quite relevant to modern competition fuelled by employment market. Nobody is ready to invest in educated candidates who just can "say something". Nowadays the effective communication is among the highest priorities and due to Forbes' official report, communication is listed among 5 top soft skills a modern employer requires ${ }^{1}$. Consequently, the desire to provide an effective law education initiates the myriad of interdisciplinary studies involving linguistics, pedagogics, methodology, sociology and many others. They all have one thing in common - honing of a highly qualified legal professional. The intersections of the previously mentioned disciplines are constructing a bridge between branches of law, education, and communication enabling a researcher of language to mount the cross disciplinary investigation by adjusting study material and some issues from legal professional environment as empirical data for linguistic analysis. The question under investigation is of high importance due to the fact that it aims to combine human professional activity, learning, and teaching of Legal English vocabulary with the ways all are enquired in artificial environment of a university classroom. This makes the research to satisfy the need for practical and applicable novelty to be theoretically pillared and explained.

The tapestry of works concentrating upon the language factor in legal profession introduces the considerable basis for terminologists, applied linguists, specialists in pedagogy, philosophy, and other sciences. Particularly, an interdisciplinary research of law, its associated texts and norms of legal discourse are awarded specific attention from prospective of language philosophy, its social impact involving the elements of critical semiotics and rhetoric by P. Goodrich (Goodrich, 1987). The comprehensive study of legal English as a communication medium is introduced by

${ }^{1}$ Adi Gaskell.What Are The Top 10 Soft Skills For The Future Of Work?. Forbes (online version). Feb 22, 2019. URL: https://www.forbes.com/sites/adigaskell/ 2019/02/22/what-are-the-top-10-soft-skills-for-the-future-of-work/\#364c868b7f1f. 
P. Tiersma ${ }^{2}$, L.M. Solan, J. Ainsworth, and R.W. Shuy ${ }^{3}$. The latter is profoundly researched in terms of strategies attributed to multilingual environment by $\mathrm{D}$. $\mathrm{Cao}^{4}$. The practical cooperation basis of a forensic linguist and a trial lawyer is outlined by R.W. Shuy ${ }^{5}$. The lingual aspects of rape and bankruptcy trials, phonetic and pragmatic peculiarities of interviews and testimonies as well as some intertextual and multicultural courtrooms' environments are discussed by D. de Carvalho Figueiredo, Ch. Heffer, S. Bernstein, M. Coulthard, A. Johnson, G. Stygall, R. Moekitsi ${ }^{6}$ and finally the work of R.C. Wydick covering the pieces of practical advice to those studying legal language introduces the attempt to simplify EFL (English as Foreign Language) classes in graduate education. The scope offered by Richard C. Wydick in his " Plain English for Lawyers"7 explains the importance of omitting or reducing the usage of the surplus lexis, too complex and long syntactical constructions, old fashioned phrases and words that might seem offensive or those, the application of which requires solid evidence and legal grounding. All in all the space for the research combining practical teaching methods, challenging pedagogical recommendations with semasiological and onomasiological approaches is left vacant. The paper aims at providing the practical tool for Legal English vocabulary teaching and learning, which is undermined by frame semantics, onomasiology, and semasiology. It is hypothesized that frame semantics serves as a binding instrument between theory of linguistic methods and their utilization in professional English Language teaching.

The objectives of the research are:

- to figure out the process of professional glossary formation;

- to elicit the stages and methods of frame-based vocabulary formation;

- to outline the modern educational means of successful application of frame-based vocabulary teaching and learning;

- to describe the perspectives of frame-based vocabulary application to both learning environment and future legal career.

2 Tiersma P. Legal English. University of Chicago Press. The USA. 1999.

${ }^{3}$ Solam L.A., Ainsworth J. Shuy R.W. Speaking of Language and Law / Edited by Lawrence M. Solan, Janet Ainsworth, and Roger W. Shuy. Oxford University Press. Oxford. UK. 2015.

${ }^{4}$ Cao D. Translating Law. Multilingual Matters Ltd. Clevedon. Buffalo. Toronto. The UK. The USA. Canada. 2007.

${ }^{5}$ Shuy W.R. Linguistics in the courtroom: a practical guide. Oxford University Press. Inc. New York. The USA. 2006.

${ }^{6}$ Cotterill J. Language in the Legal Process / Ed. by Janet Cotterill. Palgrave Machmillan Ltd. The UK. 2002

7 Wydick R.C. Plain English for Lawyers. California Law Review. Vol. 66. 1978. P. 7-31. DOI: 10.15779/Z38T44G. 


\section{Experience-based approach to Legal English Vocabulary}

The statement that people encounter the situations based on framing is not new and some examples of its application are dated back to researches: 1) on artificial intelligence done by M. Minsky (1974), later the paper was reprinted in The Psychology of Computer Vision (1975), Mind Design (1981), Cognitive Science (1992); 2) on frame semantics articulated by Ch.J. Fillmore in Frame Semantics (1982), Frames and the Semantics of Understanding (1985); 3 ) on cognitive linguistics and lexicology offered by S.A. Zhabotynska in Principles of building conceptual models for thesaurus dictionaries (2010). Thus the situations which a human faces in terms of frame structures launch two different processes such as evoked framing and invoked framing. The difference between evoked and invoked frames lies in presence of a certain amount of knowledge serving the particular situation (frame) either to get evoked/retracted from already existing experience or to be invoked/formed afresh while undergoing it ${ }^{8}$. The content of a frame depends on the peculiarities of the event it depicts and accordingly, there are surface syntactic frames determined by the structures of noun and verb; surface semantic frames with action-centred meanings of words primary containing qualifiers and relations concerning participants (agents and patients), instruments, trajectories, strategies, goals, consequences, and side-effects; thematic frames which are scenarios based on topics, activities, portraits, and settings; narrative frames: frameworks for typical stories, explanations, and arguments. Here belong conventions about foci, protagonists, plot forms, development, etc. Their aim is to aid a listener to construct a new, instantiated thematic frame in their own mind ${ }^{9}$. Also, due to M.A. Minsky the structure of a frame is predetermined by two levels the "top level" which corresponds the always true facts and the lower level actualized in form of terminals or slots which are filled by various data pertaining to the situation. Consequently, one can make a conclusion that lower slots of the frame represent a variable part of the whole structure and are the means of fixing of some new or additional knowledge on the situation enclosed within the frame and thus remaining fixed and getting accumulated in human mind.

Thus the lower level of frame with the slots filled by information performs the function of a "recorder" of new ideas and notions in human mind by attaching them to already existing frames. Also frames can be differentiated into the Thing Frame, the Action Frame, the Possession

${ }^{8}$ Fillmore Ch.J. Frame Semantics. Linguistics in the Morning Calm Selected Papers from SICOL-1981. Korea. Hunshin Publishing Company. Seoul. 1982. P. 110-137. URL: http://brenocon.com/Fillmore\%201982_2up.pdf (Last accessed: 20.10.2019).

9 Minsky M.A. Framework for Representing Knowledge. MIT-AI Laboratory Memo 306. 1974. URL: https://web.media.mit.edu/ minsky/papers/Frames/frames.html (Last accessed: 15.03.2020). 
Frame, the Identification Frame, and the Comparison Frame ${ }^{10}$ pertaining to the type of relations between the slots as the structural constituents of the frame. Each type of frame crystalizes itself via different variations of schemata. The application of a frame structures as generalized knowledge about a particular event can be particularly useful for development of professional vocabulary and Legal English vocabulary can be taken as an example. Since vocabulary formation is a dynamic, steadily developing process and thus a time consuming in terms of learning, the usage of frame approach can optimise its categorization and systematization to faster and easier process. To apply the latter to the university learning environment it is necessary to work out some methodological grounding for the frames to be applied in teaching Legal English vocabulary. Moreover, it is necessary to specify the situations/events, which will serve as building blocks for Legal Vocabulary corpus and thus are of prime importance for learners.

\subsection{Methodological platform}

The methods to utilise while approaching Legal English vocabulary in terms of frames undermine two interconnected aspects, which embody the unity of onomasiological and semasiological paradigms ${ }^{11}$. The onomasiological approach is focused on approaching the lexis from the perspective it is used by the participants of a situation, while the semasiological one covers the semantic analyses of the lexis ${ }^{12}$. The analysis develops in several stages and can be described as follows.

Table 1

\section{Procedure of Frame-based Analysis}

\begin{tabular}{|c|c|c|}
\hline & Semasiological aspect & Onomasiological aspect \\
\hline Stage 1 & Integrative defining & \\
\hline Stage 2 & Composite defining & Situation-based sorting \\
\hline Stage 3 & $\begin{array}{l}\text { Spotting the basic } \\
\text { constituents }\end{array}$ & Identifying the slots \\
\hline Stage 4 & Corpus Fracturing & $\begin{array}{l}\text { Outlining the } \\
\text { pattern/scheme }\end{array}$ \\
\hline
\end{tabular}

10 Zhabotynska S.A. Principles of building conceptual models for thesaurus dictionaries. Cognition, communication, discourse. International On-line Journal. 2010. 1. P. 72-92. DOI: 10.26565/2218-2926-2010-01-0. URL: http://sites.google.com/site/ cognitiondiscourse/vypusk-no1-2010 (Last accessed: 30.01.2019).

Onomasiology and Semasiology. URL: https://www.christianlehmann.eu/ termini/onomasiology\&semasiology.html (Last accessed: 25.06.2019).

${ }^{12}$ Dunaievska O.V., Chaiuk T.A. Modifying "Breaking Bad News" Communication: Cross-Cultural and Cognitive-Semantic Approaches. Academic Journal of Interdisciplinary Studies. 9(2). 2020. DOI: 10.36941/ajis-2020-0017. URL: http://www.richtmann.org/journal/index.php/ajis/issue/view/266 (Last accessed: 20.04.2020). 
Table 1 contains the stages of notions' analysis with their onomasiological and semasiological reference. On stage 1 the integrative defining takes place, which is focused on searching the number of notion's definitions available and providing an account of the results. The application of the integrative defining aims at determining the number of dictionary articles explaining the analysed notion which at the same time function as "containers for universal knowledge" on the issue. On stage 2 the content of definitions is sorted out based on their reference to the situation. On stage 3 the constituents which can serve as basic categories for the rest of the corpus content are spotted. The basic categories represent the slots in terms of frame structure which are to be filled with the lexical corpus verbalising the analysed situation. On stage 4 the lexis is sorted with its class reference and the scheme of the frame containing the universal understanding of the notion and the situation connected with it is outlined.

\subsection{Integrative \& Composite Defining with Situation-based Sorting}

Integrative defining and composite defining is based on analysis of the articles offered by several dictionaries. The definitions are sorted according to the categories: names/synonyms, actions, background, institutional reference, other people involved, processes involved. The latter are filled with the lexis, which is illustrated in Table 2.

Table 2

\section{Composites of Integrated Defining of lawyer}

\begin{tabular}{l|l|l|l|l|l|l}
\hline Dictionary & $\begin{array}{l}\text { Names / } \\
\text { synonyms }\end{array}$ & Actions & $\begin{array}{c}\text { Back- } \\
\text { ground }\end{array}$ & $\begin{array}{c}\text { Institu- } \\
\text { tional } \\
\text { refere-nce }\end{array}$ & $\begin{array}{c}\text { Other } \\
\text { people } \\
\text { involved }\end{array}$ & $\begin{array}{l}\text { Processes } \\
\text { involved }\end{array}$ \\
\hline $\begin{array}{l}\text { Duhaime' } \\
\text { s Law } \\
\begin{array}{l}\text { Dictio- } \\
\text { nary }\end{array}\end{array}$ & individual & $\begin{array}{l}\text { give legal } \\
\text { advice to } \\
\text { others; } \\
\text { to } \\
\text { represent } \\
\text { others; }\end{array}$ & $\begin{array}{l}\text { has been } \\
\text { certified } \\
\text { trained in } \\
\text { the law }\end{array}$ & & & litiga-tion \\
\hline $\begin{array}{l}\text { Merriam } \\
\text { Webster }\end{array}$ & someone & $\begin{array}{l}\text { to conduct } \\
\text { lawsuits } \\
\text { for; } \\
\text { to advise }\end{array}$ & & & client & $\begin{array}{l}\text { lawsuit; } \\
\text { legal } \\
\text { rights and } \\
\text { obligation } \\
\text { s; other } \\
\text { matters; }\end{array}$ \\
\hline
\end{tabular}

\footnotetext{
${ }^{13}$ Duhaime's Law Dictionary. URL: http://www.duhaime.org/LegalDictionary/l.aspx.

${ }^{14}$ Merriam Webster Dictionary. URL: https://www.merriamwebster.com/dictionary/lawyer.
} 
Table 2 (continuance)

\begin{tabular}{|c|c|c|c|c|c|c|}
\hline Dictionary & $\begin{array}{c}\text { Names / } \\
\text { synonyms }\end{array}$ & Actions & $\begin{array}{l}\text { Back- } \\
\text { ground }\end{array}$ & $\begin{array}{c}\text { Institu- } \\
\text { tional } \\
\text { refere-nce }\end{array}$ & \begin{tabular}{|c|} 
Other \\
people \\
involved
\end{tabular} & $\begin{array}{c}\text { Processes } \\
\text { involved }\end{array}$ \\
\hline $\begin{array}{l}\text { Lexico } \\
\text { (powered } \\
\text { by } \\
\text { Oxford) }{ }^{15}\end{array}$ & $\begin{array}{l}\text { person; } \\
\text { Syn. an } \\
\text { attorney; a } \\
\text { counsellor }\end{array}$ & $\begin{array}{l}\text { to } \\
\text { practice; } \\
\text { to study } \\
\text { law }\end{array}$ & & & & \\
\hline $\begin{array}{l}\text { Collins } \\
\text { Dictio- } \\
\text { nary }\end{array}$ & person & $\begin{array}{l}\text { to advise } \\
\text { in law and } \\
\text { represent } \\
\text { them in } \\
\text { court }\end{array}$ & $\begin{array}{l}\text { to be } \\
\text { qualified }\end{array}$ & court & & \\
\hline $\begin{array}{l}\text { Vocabu- } \\
\text { lary } \\
\text { Dictionary } \\
\operatorname{com}^{17} \text {. }\end{array}$ & $\begin{array}{l}\text { a profes- } \\
\text { sional; } \\
\text { Syn. an } \\
\text { attorney, } \\
\text { a solicitor, } \\
\text { a counsel- } \\
\text { lor, a } \\
\text { barrister, } \\
\text { an } \\
\text { ambulance } \\
\text { chaser } \\
\text { (pejorati- } \\
\text { vely) } \\
\end{array}$ & $\begin{array}{l}\text { to offer } \\
\text { advice } \\
\text { about the } \\
\text { law; to } \\
\text { represent } \\
\text { someone } \\
\text { in legal } \\
\text { matters }\end{array}$ & $\begin{array}{l}\text { to be } \\
\text { qualified }\end{array}$ & & & \\
\hline $\begin{array}{l}\text { The } \\
\text { American } \\
\text { Dictionary } \\
\text { of English } \\
\text { Lan- } \\
\text { guage }^{18}\end{array}$ & & $\begin{array}{l}\text { to give } \\
\text { legal } \\
\text { advice and } \\
\text { assistance; } \\
\text { to } \\
\text { represent }\end{array}$ & profession & $\begin{array}{l}\text { court; } \\
\text { other legal } \\
\text { matters }\end{array}$ & client & \\
\hline $\begin{array}{l}\text { Macmillan } \\
\text { Dictio- } \\
\text { nary }^{19}\end{array}$ & & $\begin{array}{l}\text { to provide } \\
\text { with legal } \\
\text { advice and } \\
\text { services }\end{array}$ & profession & & people & \\
\hline
\end{tabular}

${ }_{16}^{15}$ Lexico (powered by Oxford). URL: https://www.lexico.com/en/definition/lawyer.

16 Collins Dictionary. URL: https://www.collinsdictionary.com/dictionary/ english/lawyer.

${ }_{17}^{17}$ Vocabulary Dictionary com.URL: https://www.vocabulary.com/dictionary/lawyer.

${ }^{18}$ The American Dictionary of English Language. URL: https://www.ahdictionary.com/word/search.html?q=lawyer

19 Macmillan Dictionary. URL: https://www.macmillandictionary.com/dictionary/ american/lawyer. 
Table 2 (ending)

\begin{tabular}{|c|c|c|c|c|c|c|}
\hline Dictionary & $\begin{array}{c}\text { Names / } \\
\text { synonyms }\end{array}$ & Actions & $\begin{array}{l}\text { Back- } \\
\text { ground }\end{array}$ & $\begin{array}{c}\text { Institu- } \\
\text { tional } \\
\text { refere-nce }\end{array}$ & \begin{tabular}{|c|}
$\begin{array}{c}\text { Other } \\
\text { people } \\
\text { involved }\end{array}$ \\
\end{tabular} & $\begin{array}{c}\text { Processes } \\
\text { involved }\end{array}$ \\
\hline $\begin{array}{l}\text { Cam- } \\
\text { bridge } \\
\text { Dictionary } \\
\text { online }^{20}\end{array}$ & & $\begin{array}{l}\text { to give } \\
\text { advice } \\
\text { about the } \\
\text { law; } \\
\text { to speak } \\
\text { for smb. }\end{array}$ & & court & people & \\
\hline $\begin{array}{l}\text { Your } \\
\text { Dictio- } \\
\text { nary }^{21}\end{array}$ & & \begin{tabular}{|l} 
to give \\
legal \\
advice and \\
represent
\end{tabular} & & $\begin{array}{l}\text { legal } \\
\text { matters }\end{array}$ & people & \\
\hline $\begin{array}{l}\text { Infoplease } \\
\text { (dictionar } \\
\text { y search) }\end{array}$ & interpreter & \begin{tabular}{|l|} 
to \\
interpret
\end{tabular} & \begin{tabular}{|l|} 
Mosaic \\
Law; \\
Luke 14:3
\end{tabular} & $\begin{array}{l}\text { New } \\
\text { Testament } \\
\text { The Bible; } \\
\text { church; }\end{array}$ & & $\begin{array}{l}\text { Interp- } \\
\text { retation of } \\
\text { Religious } \\
\text { Law }\end{array}$ \\
\hline $\begin{array}{l}\text { Business } \\
\text { Dictionary } \\
\text { com }^{22}\end{array}$ & & $\begin{array}{l}\text { to give } \\
\text { legal } \\
\text { advice; to } \\
\text { represent }\end{array}$ & $\begin{array}{l}\text { certified } \\
\text { as trained } \\
\text { in the } \\
\text { theory and } \\
\text { practice of } \\
\text { law; } \\
\text { licensed }\end{array}$ & $\begin{array}{l}\text { litigation } \\
\text { within a } \\
\text { particular } \\
\text { juris- } \\
\text { diction }\end{array}$ & & \\
\hline
\end{tabular}

Based on the data of Table 2 the integrated definition of a lawyer is: $\boldsymbol{a}$ professional (syn. attorney, counsellor) such as a solicitor or barrister, who is qualified or certified to give legal advice and services in rights, obligations or litigation within a particular jurisdiction and who can speak for a client in the court. Also, there exists an archaic definition of lawyer as a person who interprets Mosaic Law mentioned in The Bible (New Testament) by Luke 14:3. Thus the modern notion of lawyer can be crystalized in ACTION FRAME SCHEME: Someone (Agent) --- acts for --Someone (Patient):

- SLOT AGENT: professional, attorney, counsellor, solicitor, barrister;

- SLOT TO ACT FOR: to offer advice about the law, to represent someone in legal matters, to interpret law, to speak for somebody, to provide

${ }^{20}$ Cambridge Dictionary online. URL: https://dictionary.cambridge.org/dictionary/ english/lawyer.

${ }^{21}$ Your Dictionary. URL: https://www.yourdictionary.com/lawyer.

22 Business Dictionary com. URL: http://www.businessdictionary.com/definition/ lawyer.html. 
with legal advice and services, to practice; to study law, to give legal advice and assistance, to speak for somebody;

- SLOT PATIENT: client.

To sum the data of the research up, it is the lawyer who is involved in every legal issue but acts exclusively on behalf of a client. With reference to the content of the slots mentioned above one can establish direct relation to the other information on a situation connected with a lawyer like: company, law firm, drafting documents, mediation, ADR (alternative disputes resolution), drafting and signing contracts, litigants, judge, jury, witness, bailiff, other court personnel etc. The establishing of such ties can be very useful in educational process as a method of activation of the background or learning and practicing new vocabulary.

The relevance of the results demonstrated by the integrated defining of lawyer notion and the frame-based analysis of the situation a lawyer is involved in can be also underpinned by the finding of our earlier research on a lawsuit situation ${ }^{23}$. The research characterises a situation describing a lawsuit as a dynamic event (action, dispute, proceeding, act, suit etc.) happening within the court of law or a civil court that involves 2 explicit participants (individuals, parties, plaintiff, defendant). Lay definitions of a lawsuit such as a case, problem, claim, dispute are embodied in ACTION FRAME: WHO (person) -- ACTS (seeks a remedy from) -- WHO (person). A lawsuit is referred to as a legal action, suit, proceeding "at the very moment it enters the area of court of law" 24 and is served by the frame: WHO (plaintiff) -- ACTS (sues) -- WHO (defendant). According to the data obtained while frame-based analysis of lawsuit situation a lawyer can be characterised as an Instrument of an Agent (their client) of frame LAWSUIT. Grounding on the integrated defining of lawyer and the fact that frame LAWYER corresponds to the scheme of ACTION frame, where the lexis used for verbalization of a legal professional belongs to slot AGENT, gives the opportunity to position a lawyer as Secondary Agent while analysing the legal matters by using the frame-based analysis.

To conclude, the basic frame LAWYER is viewed as a universal instrument for being applied to build the Legal English students' vocabulary on the other topics. In terms of usage of frame-based vocabulary approach the function of a lawyer in situations/events happening to a client is fixed in frame LAWYER and thus the lexis from the slots and their

\footnotetext{
${ }^{23}$ Dunaievska O.V. Function of a Lawyer: Frame Approach. Science and Education a New Dimension. Humanities and Social Sciences. Vol. VIII (37). 2020. P. 37. DOI: 10.31174/SEND-HS2020-223VIII37-08. URL: https://seanewdim.com/uploads/ 3/4/5/1/34511564/hum_viii_223_37.pdf(Last accessed: 20.04.2020).

${ }^{24}$ Dunaievska OV. Function of a Lawyer: Frame Approach. Science and Education a New Dimension. ... P. 36
} 
interrelation may be implied in the frames of the other situations presupposing legal advice.

\subsection{From basic Constituents to Frame Pattern Scheme}

Having analyzed the study material on Intellectual Property ${ }^{2526}$ the basic frame serving intellectual property events is ACTION FRAME: Somebody/Agent --- acts (on) --- Something/Patient. Intellectual property events can be described via following action frames:

1) Somebody (Agent) -.- invents/creates (Acts) -.- Something

\section{(Patient)}

- SLOT AGENT: artiste, inventor, innovator, craftsman, examiner;

- SLOT TO ACT: to create, to improve, to elaborate;

- SLOT PATIEN: items of intellectual property, geographical indication, layout design, industrial design, integrated circuit IC, technical drawing, technique, name, original works of authorship, search engine, safety valve, plain-paper copier, create a device, manual process, metal alloy, a know-how, mode of manufacture;

2) Somebody (Agent) -.- cooperates with (Acts) -.- Somebody (Patient)

- SLOT PRIME AGENT: artiste, inventor, innovator, craftsman, examiner, right holder;

- SLOT SECONDARY AGENT: a lawyer;

- SLOT TO ACT: to franchise, to transact, to confer the right, to embody, to exploit an invention, to exploit a person's name or image, to quote passages, to acquire permission, to vest in/with, to credit, to assign the copyright (to another), to approve patent application, to pay royalties, to take out a patent, to merchandise, to launch a product, to intrust;

- SLOT PATIENT: enterprise, company;

- SLOT INSTRUMENTS: incentive, customer list, marketing methods, pricing data, reverse engineering, promotional purposes;

3) Somebody (Prime Agent and Secondary Agent) --protects/registers --- (Acts) Something (Patient)

- SLOT PRIME AGENT: artiste, inventor, innovator, craftsman, examiner rights holder;

- SLOT SECONDARY AGENT: lawyer;

- SLOT TO ACT: to apply for (a copyright protection), to be granted, to be licensed out, review by case-by-case basis, to issue, to allow ownership, to meet the tests of novelty, to circulate, to guard, to gain

${ }^{25}$ Callan H., Edwards L. Absolute Legal English, Delta Publishing. 2010. P. 10-18.

${ }^{26}$ Wyatt R. Property. Check you English Vocabulary for Law. A\&C Black. London. 2006. P. 52-53. 
competitive advantage, to certify origin/quality, to submit an application for, to notify an applicant;

- SLOT PATIENT: trademark, intangible assets, intellectual property, trademark, geographical indication, exclusive rights copyright, protection, industrial design, layout design, integrated circuit IC, technical drawing, technique, brand name, original works of authorship, safety valve, device, a know-how, trade secret, mode of manufacture, Underwriters' Laboratories, Inc. UL;

4) Somebody(Agent) -.- violates (Acts) --- Something (Patient)

- SLOT AGENT: mastermind of the theft, forger, wrongdoer;

- SLOT TO ACT: to violate, to exploit an invention, to exploit a person's name or image, to infringe, to challenge a patent, to reveal a secret, to preclude;

- SLOT PATIENT: exclusive rights, trademark, geographical indication, a copyright;

5) Somebody(Prime Agent and Secondary Agent) --- sues (Acts) --Somebody (Patient)

- SLOT PRIME AGENT: rights holder;

- SLOT SECONDARY AGENT: lawyer;

- SLOT TO ACT: to sue for competing concerns/espionage/disclose a patent publicly/public disclosure/cyber-attack/changing names midstream, seek damages for copyright infringement, seek an injunction, to pursue an exclusion action, to keep the product out of, challenge a patent, to assert a right to ownership, to stall an application, to institute proceedings, to allege violations, to exonerate;

- SLOT PATIENT: mastermind of the theft, forger, wrongdoer;

- SLOT INSTRUMENT: a negotiating process, mediate a dispute, territorial claims;

6) Somebody (Agent) ---punishes (Acts)--- Somebody (Patient)

- SLOT AGENT: arbitrator, jury, International Trade Commission, federal statute, Patent and Trademark Office;

- SLOT TO ACT: to exclude, to prohibit unauthorized use, to assign the copyright (to another), to qualify as, to diminish requests;

- SLOT PATIENT: forger, wrongdoer;

Also the data collected on intellectual property illustrated the presence of one more situation which is represented by POSSESSION FRAME ${ }^{27}$ :

Somebody / Owner --- owns / has --- Something/Possession

27 Zhabotynska S.A. Principles of building conceptual models for thesaurus dictionaries. Cognition, communication, discourse. International On-line Journal. 2010. P. 83. 
- SLOT OWNER: artiste, inventor, innovator, craftsman, examiner, rights holder; business partner, educator;

- SLOT OWNS / HAS: to own, to have, to enjoy;

- SLOT SOMETHING: permission, patent, trade secret, trademark, industrial design, layout design, integrated circuit IC, appellation, technique, brand name, amount and substantiality, rights secured by the patent, a know-how, seal of approval, certification mark, presumptive right, right of publicity ownership, original works of authorship, public domain, the right to fair use, the right to exclude others from.

At first, the learners may argue the relevance of using the identical slot PATIENT in frames Somebody/Agent protects (registers)/Acts Something/Patient and Somebody/Agent invents (creates)/Acts Something/Patient due the identical vocabulary set their slots are filled the slots with, but the vital significance of both frames lies in the fact that they distinctly demonstrate the implicated role of a legal professional or a lawyer in the second frame. The legal assistance makes the event happen and the law on Intellectual Property comes into force.

\section{M-O-V-E Approach to Teaching and Learning Frame-based Vocabulary}

The basis of this approach is simulation of professional environment by selecting the optimal set of educational methods, tools, and strategies applied to educational process. The extension of framed-vocabulary model encloses the variety of modern educational opportunities, driven by the educational paradigm of Student-centred Learning $(\mathrm{SCL})^{28}$. The approach simultaneously appeals to variety of the learning strategies and provokes students to think critically. The latter is of vital importance for lawyers ${ }^{29}$. It is necessary to mention that to fulfil the framed-vocabulary implementation in the classroom and to certify its continuous upgrading the four-staged educational scenario M-O-V-E, extending from vocabulary acquiring to its limitless expending through life-long application, is offered. Each level maintains situational links established through framebased approach and serves as a proper educational "vehicle" that will fit the learning environment and thus will be able to merry theory and practice necessary to make Legal English teaching and learning the interactive processes. The four-staged construction corresponds the "M-O-V-E" approach to legal English frame-based vocabulary formation in terms of

\footnotetext{
${ }^{28}$ Brandes D., Ginnis P. A Guide to Student-centered Learning. Oxford. Blackwell. 1986.

${ }^{29}$ Segaller T. Critical Thinking Skills Are Vital to Working in Law. Lawyer Monthly. December 10, 2019. URL: https://www.lawyer-monthly.com/2019/10/critical-thinkingskills-are-vital-to-working-in-law/ (Last accessed: 20 March 2020).
} 
modern perception of educational process, where $\mathbf{M}$ refers to Motivation (the first stage of acquiring vocabulary), $\mathbf{O}$ corresponds to the Opportunities (the second stage of acquiring vocabulary), $\mathbf{V}$ introduces Verification (the third stage of acquiring vocabulary), and $\mathbf{E}$ signifies Engagement (the fourth stage of acquiring vocabulary). "M-O-V-E" approach to Legal English vocabulary building covers each stage of activation the certain amount of requirements to conducting educational process.

\subsection{Critical Thinker}

"Education is not the learning of facts but training of the mind to think" (Albert Einstein). The statement of Albert Einstein corresponds the very skill the legal professionals are expected to acquire. The research offered by $\mathrm{W}$. Henderson encompasses problem solving, legal analysis and reasoning, legal research, factual investigation, counselling, negotiation, communication, litigation and ADR, organization and management of legal work, recognizing and resolving ethical problems as the skills crucial for legal professionals $^{30}$. All of the skills mentioned necessitate the sequential complication of a university curriculum in terms of sorting the appropriate teaching methods as well as shaping the opportunities the educator is able to provide while classes, self-study and other after-classes activities to bridge the theory with practice.

Law education, awarding always much emphasis to higher-order thinking as well as to communicative skills formation, has to prepare "effective communicators, critical and dynamic thinkers, problem solvers, and career experts" 31 making curriculum design the climate with the "objectives not limited to linguistic factors, but also include developing of art and critical thinking" ${ }^{32}$. Alternatively, there is no place for reduction of language factor in legal education, since "actual business in law is transacted and executed in language" ${ }^{33}$. In this case communication skills' development gets mandatory accompanied by critical thinking, problem solving and career advancement.

${ }^{30}$ Henderson W.D. Successful Lawyer Skills and Behaviours. Essential Qualities of the Professional Lawyer / Edited by P. A. Haskins. American Bar Association. ABA Standing Committee on Professionalism. Center for Professional Responsibility. 2013. P. 53-68. URL: https://static1.squarespace.com/static/58d9b495be6594a702757b50/ t/590f794b29687fab6a08adac/1494186316428/Successful+Lawyers+Skills+and+Behavio rs.pdf (Last accessed: 23.08.2019).

31 Živković S. A Model of Critical Thinking as an Important Attribute for Success in the 21st Century. Procedia - Social and Behavioral Sciences. Vol. 232. 2016. P. 102. DOI: $10.1016 /$ j.sbspro.2016.10.034.

${ }^{32}$ Brown H.D. Some practical thoughts about student-sensitive critical pedagogy. The Language Teacher. Vol. 28(7). 2004. P. 24.

33 Essential Study Skills for Law Students. Routledge. Taylor\&Francis Group. P. 67. URL: https://www.crcpress.com/rsc/downloads/Essential_Study_Skills_for_Law_ Students_FINAL_PDF.pdf (Last accessed: 14.08.2019). 
Critical thinking is sequentially elicited in B. Bloom's Taxonomy ${ }^{34}$ : remember $\rightarrow$ understand $\rightarrow$ apply $\rightarrow$ analyze $\rightarrow$ evaluate $\rightarrow$ create. Thus, the studying of frame-based vocabulary is applied according to the next elements:

- recalling the facts and basic concepts by memorizing, repeating number of the situations (frames);

- explaining ideas and concepts by classifying, translating, selecting the corpus of lexis according to the situations;

- using information in new situations by implementing, sketching, scheduling while dealing with the new material;

- drawing connections by contrasting, comparing, and criticizing the usage of already familiar lexis in different situations;

- justifying a stand or decision by appraising, arguing, and supporting the usage of the acquired lexis in simulated legal environment (for example: mooting);

- producing new original work by developing, designing, assembling, constructing, and investigating the new vocabulary items through engagement into legal assistance as a paralegal in a law clinic.

Being a compulsory part of university studies, critical thinking is highly requested and valued by tertiary educators ${ }^{3536,}$ especially by those teaching law, since legal analysis and reasoning occupy the significant place among ten fundamental skills and professional values requested by American Bar Association $^{37,38}$. Critical thinking presupposes the sceptical reflection, reasoned way of thinking, utmost attention, and observation ${ }^{39}$ that is why the skill requires the incorporation of professional either simulated or natural environment into the study process. Alternatively, a student, who is thinking critically, acquires the ability of social context assessment, the contributions

34 URL: https://teaching.uncc.edu/sites/teaching.uncc.edu/files/media/files/file/Goals AndObjectives/Bloom.pdf.

35 Moore T. Critical thinking: Seven definitions in search of a concept. Studies in Higher Education. Vol. 38(4). 2013. P. 506-522. DOI: 10.1080/03075079.2011.586995.

${ }^{36}$ Wilson K. Critical reading, critical thinking: Delicate scaffolding in English for Academic Purposes (EAP). Thinking Skills and Creativity. 2016. P. 256. DOI: $10.1016 /$ j.tsc.2016.10.002.

${ }^{37}$ Seize the Future: Forecasting and Influencing the Future of the Legal Profession / Edited by G.A. Munneke. American Bar Association. Section of Law Practice Management. 2000.

${ }^{38}$ Munneke G.A. Legal Skills for a Transforming Profession. Pace University School of Law. Vol. 22. 2001. P. 132. URL: http://digitalcommons.pace.edu/plr/vol22/iss1/3 (Last accessed: 03.09.2019).

${ }^{39}$ Ennis R.H. A Taxonomy of Critical Thinking Dispositions and Abilities / Edited by J. Baron and R. Sternberg. Teaching thinking skills: Theory and practice. New York. P. 11. 
to be made, and the issues to be solved ${ }^{40}$. Nonetheless, due to the fact that it does not belong to natural traits of personality and is usually defined as ""set of methods aimed at exploring in a particular way"41 the learning environment has to be designed as a challenging and not proving with readymade answers. The following hand-out on Intellectual Property predetermined by frame-based vocabulary can be offered as an example:

Table 3

Fragment of frame-based sample of educational hand-out

\begin{tabular}{|c|c|c|c|}
\hline \multicolumn{3}{|c|}{ IP glossary Categories } & Vocabulary \\
\hline \multirow{8}{*}{ 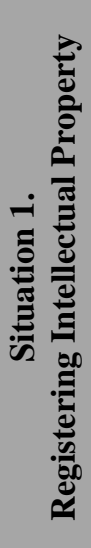 } & \multirow{3}{*}{ somebody } & legal professional & IP attorney \\
\hline & & client & an artist \\
\hline & & other & a paralegal \\
\hline & \multirow{3}{*}{ acts } & legal professional & $\begin{array}{c}\text { to advise on copyright } \\
\text { matters }\end{array}$ \\
\hline & & client & $\begin{array}{c}\text { to apply for copyright } \\
\text { protection }\end{array}$ \\
\hline & & other & to collect data \\
\hline & \multirow{2}{*}{ something } & pieces of art & picture \\
\hline & & methods & $\begin{array}{c}\text { suturless jointing } \\
\text { of body tissues }\end{array}$ \\
\hline
\end{tabular}

The fragment of frame-based vocabulary sample of educational hand-out provided in Table 3 illustrates the possible application of the method earlier elicited throughout paragraphs 1.2.-1.4. The part of the table marked by the darkest shade directly refers to the basic frames and their slots associated with intellectual property situations, the lighter part of the table contains the further division of the slots into categories which can aid easier sorting process conducted by learners while dealing with the Intellectual Property glossary (a corpus of lexis previously devised by an educator). This part or the amount of the categories the learners are provided with can vary depending on the aims planned to be fulfilled and the method of teaching to

${ }^{40}$ Freire P. Pedagogy of the Heart. New York. The Continuum. 1997. P. 14.

${ }^{41}$ Cottrell S. Critical Thinking Skills. Developing Effective Analysis and Argument. Palgrave Macmillan LTD. The UK. 2005. P. 2. URL: https://elearn.uni-sofia.bg/ pluginfile.php/76858/mod_resource/content/1/\%5BStella_Cottrell\%5D_Critical_Thinking _Skills_Develo(BookFi.org).pdf (Last accessed: 20.08.2019). 
be applied. The colourless part of table 2 contains the examples of sorted lexical units and is intentionally filled for demonstration purposes. It is recommended to be left empty by the educator, since it is to be filled by the learners while analysing the corpus of lexis.

The example of frame analysis applied to intellectual property situations enables the educators/learners to use it whilst studying the other areas of law: Tort Law, Contract Law, Criminal Law etc. by simultaneously developing the set of thinking skills which prepare grounding for critical thinking through the following actions: by categorizing the participants of the situation as those pertaining to the particular area of law, participant of the situation, instrument, action, location, that means recognizing them in particular context, identifying their characteristics and shaping prior judgment on them. In other words the knowledge on framed-vocabulary serves the basis for spotting the denoted meanings with the help of which vital connoted ${ }^{42}$ meaning can be sorted out. The latter serves as the platform for critical and analytical thinking skills development that are regarded as crucial for university law education and future professional environment ${ }^{43}$.

\subsection{Grounding for $\underline{M O T I V A T I O N}$}

Year 1999 is considered to be an upgrading point that has launched Modern European Higher Education Area (EHEA). Based on the decision of 29 Ministers responsible for higher education the new view of a university student was officially accepted. The principles of transparency, mobility, and great emphasis on the learners as the proactive and thus motivated ones left no space for the latter to be passive recipients of knowledge. When the paradigm shift becomes obvious, the era of a teacher as the only trusted source of knowledge and experience is behind. The issue is reflected in the guidelines provided is by D. Branndes and P. Ginnis, where a student accepts responsibility of planning the curriculum that results in full understanding of their place in the studying process of student-centred learning (SCL) ${ }^{44}$. Consequently, there is a need to refocus the understanding of academic teaching staff from classical perceiving of a teacher, postulated by teacher-centred paradigm (as one who transmits information) to a facilitating mentor who aids in constructing knowledge by students

\footnotetext{
${ }^{42}$ Meaning that carries additional or unstated, latent meanings and implications, these may be obvious but very often concealed (Cottrell, 2005: 95)

${ }_{43}$ Cottrell S. Critical Thinking Skills Developing Effective Analysis and Argument. ... P. 17.

${ }_{44}$ Wilson K. Critical reading, critical thinking: Delicate scaffolding in English for Academic Purposes (EAP). Thinking Skills and Creativity. 2016. P. 256. DOI: 10.1016/j.tsc.2016.10.002.
} 
themselves ${ }^{45}$. As the result, higher educational establishment turns from place of knowledge translation to a place where knowledge is acquired.

All in all the transparent and applicable education in modern university environment will embrace both the methods addressing SCL paradigm's challenges and those appealing the sequential activities connected with creativity, critical thinking and professional expertise. In this way there is a possibility for modern law school to get redesigned in order to educate a primarily motivated learner, who is potentially prepared to acquire knowledge and develop skills being fully engaged in the educational process by an experienced facilitator, who in their turn are to strengthen the motivation in their students.

\subsection{Selecting the $\underline{O P P O R T U N I T I E S}$}

Whilst the modernized SCL model of education the question "How to perform?" looms the universities' horizons. This can be addressed by some bright examples of effective alternatives to lectures, assignments, and exams for summative purpose that is particularly a mix of FLIPped Learning, Active Learning, Collaborative Learning, Cooperative Learning and other.

Stemming from Harvard Professor E. Mazur's "peer instruction" and "just in time teaching" 46 the new turn gets successfully implemented as "classroom flip" and is assessed by J.W. Baker as a quite effective tool for provoking student to learn actively with the teacher "by their side"47 FLIPped learning, was further popularized by J. Bergman and A. Sams ${ }^{48}$ and grew into an innovative media to facilitate in academic classroom. In fact, the principle of FLIPed Learning is a study approach in which the conventional perception of a classroom is replaced by flipping it into an environment where the students face problem solving activities based on applying background knowledge gained through coping with their home assignments. This provides an opportunity to apply the corpus of already analysed individually information into the situations modelled by a teacher in class hours. Consequently, the conventional educator-student interaction, that is crystallized through teacher-centred paradigm, is transformed into mentor/facilitator with active learner cooperation model, required by student-centred paradigm. This gets schematized as the following:

${ }^{45}$ Brandes D., Ginnis P. A Guide to Student-centered Learning. Oxford, Blackwell. 1986. P. 12.

${ }^{46}$ Crouch C.H., Mazur E. Peer Instruction: Ten Years of Experience and Results. American Journal of Physics. Vol. 69. 2001. P. 970-977.

${ }^{47}$ Baker J.W. The "Classroom Flip": Using Web Course Management Tools to Become the Guide on the Side. In: the 11th International Conference on College Teaching and Learning: Jacksonville. Florida. 2000.

${ }^{48}$ Bergmann J., Sams. A. Flip Your Classroom: Reach Every Student in Every Class Every Day. International Society for Technology in Education. ISTE and ASCD. 2012. 


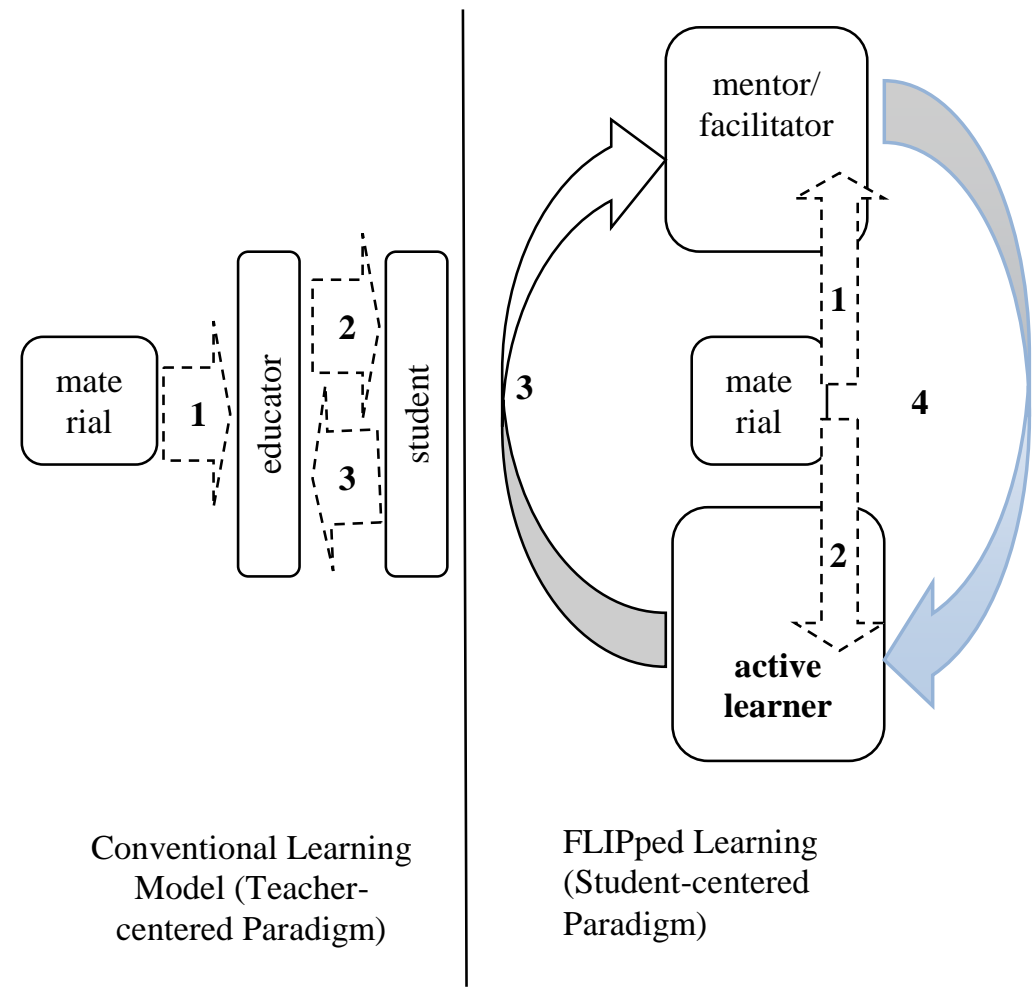

Figure 1. Teaching Paradigm Transformations

The processes depicted in Figure 1 addresses the flow of information labelled from its starting point marked with " 1 " to the assessment and recommendations that correspond numbers " 3 " in teacher-centred paradigm and " 4 " in student-centred paradigm. The key focus of figure 1 falls upon the transformation of learning process of the participants and the type of their interaction in the classroom. The learners get the equal excess to the authentic information, but not the one that has been reflected by the teacher (in teacher-centred paradigm). Additionally, the students earn an opportunity to be active users of their background knowledge and acquire skills in this process that makes them active learners, not bound by bias and thus moving towards creativity put by B. Bloom on the highest level facilitated in learning environment. FLIPped learning applied to teaching vocabulary for law presupposes a student to cope with basic terms needed for the class in independently, but since the lexis is new it, obviously, cannot be correlated with an already familiar situation or has no frame to evoke. In this case there 
are at least two aiding tools: facilitation and framing. In other words, a learner has to deal either with acquiring background knowledge prior to studying vocabulary and is supplied by a frame-based vocabulary hand-out (see Table 2 as an example) to be filled in which is FRAMING. The actions like forming the lexical corpus, identifying the set of the situations serving the particular topic, and giving the instructions have to be made prior by a teacher and refer to as FACILITATION. The latter, being implemented in the study process in OPPORTUNITIES stage, constructs the basis for independent frame-based analysis and is to be steadily practiced by a learner during stages of VERIFICATION and ENGAGEMENT.

Thus, FLIPped learning provides the possibility for launching whilst legal English class various types of thinking skills, moreover it enables the teacher-facilitator to interact with not only motivated learners, but also "equipped" in terms of essential vocabulary and background information. On one hand, FLIPped Learning helps the learners: 1) personalize the learning process (they are free to choose the location, aids, medium, and time); 2) form independent study procedure; 3 ) set their own guidelines and priorities; 4) develop and apply critical thinking; 5) encourage creativity. On the other hand, FLIPped Learning crystallizes the particular features of a mentor/facilitator as one, who, with accuracy and proficiency: 1) selects a needed portion of information; 2) works out the set of necessary instructions and shapes the timelines for the information to be processed by the learners; 3 ) provides the learners with the utmost assessment; 4) continuously advances and is open to self-education; 5) has an opportunity to encourage the further advancement of each learner by the analysis of the processed information through application of the range of student-centred paradigm methods, among which are Problem Based Learning (PBL), Project Learning (PL) and many others.

A composition of PBL and PL in teams or small groups refers to approaches successfully fitting Legal English classroom due to several reasons. Firstly, PBL provokes learners' scaffolding by engaging schemata previously formed while acquiring frame-based approach to vocabulary activities. Secondly, PL in teams gives the learners basic experience and trains team work compulsory required by legal firms ${ }^{49}$. Also, PBL and PL can be viewed as classroom activities through pair work, team work, for applying the method of sorting the frame-based vocabulary.

\subsection{Postulating $\underline{V}$ ERIFICATION and $E N G A G E M E N T$}

Undergoing the first two stages of M-O-V-E approach and having thematic vocabulary look like already sorted and ready to be evoked one, the

\footnotetext{
${ }^{49}$ Essential Study Skills for Law Students. Routledge. Taylor\&Francis Group. P. 34 35 .
} 
learners are to be well equipped for proceeding with the continuous process of enrichment of acquired and sorted vocabulary by adding new lexical items while encountering new material or situation. The VERIFICATION is reached by checking the amount and sequence of vocabulary utilized by encountering various situations. The situations may be simulated at a classroom, in mooting competitions or approached in real life by participating in law clinic volunteer work or giving conference reports.

The stage of ENGAGEMENT relates mostly to self-learning as far as the stage presupposes a never ending process of expending legal vocabulary not only within university studies, but also through pursuing professional career.

\section{CONCLUSIONS}

Frame-based vocabulary teaching and learning refer to the effective and practical tools of Legal English vocabulary formation. The vocabulary-based approach towards professional vocabulary formation involves preparing by the teacher forms for analysis of the previously compiled glossary of the study topic. For this an educator estimates the topic and determines the set of the situations it may encompass. Further, the situations are analyzed in terms of frames they appeal to and slots the latter split into. In educational material or hand-outs for students the slots represent containers to be filled by lexical material when they review the previously formed glossary provided by a teacher. Frame-based vocabulary application can be incorporated into the classroom environment via undergoing a four-staged M-O-V-E principle where $\mathbf{M}$ refers to Motivation, $\mathbf{O}$ - to Opportunities, $\mathbf{V}$ - to Verification, and $\mathbf{E}$ - to Engagement. Due to the principles of student-centred educational paradigm, frame-based vocabulary approach to teaching and learning can function as an integral part of methods of FLIPped Learning, Problem-based Learning or Project Learning. The utilization of frame-based vocabulary approach in teaching English in other professional environments such as health care, military service, engineering seems to be a quite possible perspective. Moreover the employing of the frame-based vocabulary approach in educational process allows an educator to develop the skills of critical thinking which is estimated as one having vital importance in successful legal career through: a) classifying, translating, and selecting the corpus of lexis according to the situations; b) repeating number of the situations (frames); c) implementing, sketching, and scheduling while dealing with the new material; d) comparing and criticizing the usage of already familiar lexis in different situations; e) appraising, arguing, and supporting the usage of the acquired lexis in simulated legal environment (for example: mooting); f) producing new original work by developing, designing, assembling, constructing, and investigating the new vocabulary items through engagement into legal assistance as a paralegal in a law clinic. Finally, the usage of framebased vocabulary in modern teaching and learning of Legal English turns 
encountering legal terms in further learning into a familiar process what makes communication in career of a legal professional be effective due to it being rather evoked (common) then invoked process and helping lawyers to communicate because they do have something to say, but not because they have to say at least something.

\section{SUMMARY}

The paper addresses the vocabulary aspect of professional communication issues. The key focus of the work is given to linguistic analysis applied in modern educational environment. The tools of frame semantics combined with semasiological and onomasiological interpretation are applied to some of legal notions in order to establish the situational and semantic peculiarities of Legal English vocabulary. The data obtained during linguistic analysis are integrated into $\mathrm{M}-\mathrm{O}-\mathrm{V}-\mathrm{E}$ principle-based guidelines for their practical application to both university learning environment and further professional career. On one hand, the cross-disciplinarian character of the paper illustrates the theoretical grounding for frame-based approach. On the other hand, it provides the set of methodological opportunities, postulated by modern educational paradigm, to be productively articulated and exercised. The paper is the direct result of stressing predominantly on advancement of the evoked legal notions accompanied by the vocabulary associated with them rather than on the invoked ones. The special attention is awarded to the possible simultaneous utilization of the framed-vocabulary formation and critical thinking skills development, as far as the latter is an indispensable part of modern legal profession.

\section{REFERENCES}

1. Aurelia M.N. Cross-cultural communication a challenge to English for legal purposes. Procedia. Social and Behavioral Sciences. Vol. 46. 2012. Pp. 5475-5479.

2. Baker J.W. The "Classroom Flip": Using Web Course Management Tools to Become the Guide on the Side. In: the 11th International Conference on College Teaching and Learning. Jacksonville. Florida. 2000.

3. Bergmann J., Sams A. Flip Your Classroom: Reach Every Student in Every Class Every Day. International Society for Technology in Education. ISTE and ASCD. 2012.

4. Brandes D., Ginnis P. A Guide to Student-centered Learning. Oxford, Blackwell. 1986.

5. Brown H.D. Some practical thoughts about student-sensitive critical pedagogy. The Language Teacher. Vol. 28(7). 2004. P. 24.

6. Callan H., Edwards L. Real Property Law. Absolute Legal English: for International Law, Delta Publishing. 2011. Pp. 56-64. 
7. Callan H., Edwards L. Absolute Legal English, Delta Publishing. 2010. Pp. 10-18.

8. Cao D. Translating Law. Multilingual Matters Ltd. Clevedon. Buffalo. Toronto. The UK. The USA. Canada. 2007.

9. Cotterill J. Language in the Legal Process / Ed. by Janet Cotterill. Palgrave Machmillan Ltd. The UK. 2002.

10. Cottrell S. Critical Thinking Skills Developing Effective Analysis and Argument. Palgrave Macmillan LTD. The UK. 2005. URL: https://elearn.uni-

sofia.bg/pluginfile.php/76858/mod_resource/content/1/\%5BStella_Cottrell\% 5D_Critical_Thinking_Skills_Develo(BookFi.org).pdf (Last accessed: 20 August 2019).

11. Crouch C.H., Mazur E. Peer Instruction: Ten Years of Experience and Results. American Journal of Physics. Vol. 69. 2001. Pp. 970-977.

12. Dunaievska O. V., Chaiuk T. A. Modifying "Breaking Bad News" Communication: Cross-Cultural and Cognitive-Semantic Approaches. Academic Journal of Interdisciplinary Studies. 9(2). 2020. DOI: 10.36941/ajis-2020-0017. URL: http://www.richtmann.org/journal/ index.php/ajis/issue/view/266 (Last accessed: 20.04.2020).

13. Dunaievska O.V. Function of a Lawyer: Frame Approach. Science and Education a New Dimension. Humanities and Social Sciences. Vol. VIII (37). 2020. Pp. 35-37. DOI: 10.31174/SEND-HS2020-223VIII37-08. URL: https://seanewdim.com/uploads/3/4/5/1/34511564/hum_viii_223_37.pdf (Last accessed: 20.04.2020).

14. Ennis R.H. A Taxonomy of Critical Thinking Dispositions and Abilities / Edited by J. Baron and R. Sternberg. Teaching thinking skills: Theory and practice. New York. Pp. 9-26.

15. Essential Study Skills for Law Students. Routledge. Taylor\&Francis Group. URL: https://www.crcpress.com/rsc/downloads/Essential_Study_ Skills_for_Law_Students_FINAL_PDF.pdf (Last accessed: 14.08.2019).

16. Fillmore Ch.J. Frame semantics. Linguistics in the morning calm. In Selected papers from SICOL-1981. 1982. Pp.110-137.

17. Freire P. Pedagogy of the Heart. New York. The Continuum. 1997.

18. Goodrich P. Legal Discourse. Studies in Linguistics, Rhetoric and Legal Analysis. Palgrave Macmillan, UK. 1987.

19. Henderson W.D. Successful Lawyer Skills and Behaviours. Essential Qualities of the Professional Lawyer / Edited by P.A. Haskins. American Bar Association. ABA Standing Committee on Professionalism. Center for Professional Responsibility. 2013. Pp. 53-68. URL: https://static1.squarespace.com/static/58d9b495be6594a702757b50/t/590f79 4b29687fab6a08adac/1494186316428/Successful+Lawyers+Skills+and+Be haviors.pdf (Last accessed: 23.08.2019). 
20. Mertz E. The Language of Law School. Oxford University Press, Inc, New York. 2007.

21. Minsky M.A. Framework for Representing Knowledge. MIT-AI Laboratory Memo 306. 1974. URL: https://web.media.mit.edu/ minsky/ papers/Frames/frames.html (Last accessed: 15.03.2020).

22. Moore T. Critical thinking: Seven definitions in search of a concept. Studies in Higher Education. Vol. 38(4). 2013. Pp. 506-522. DOI: 10.1080/03075079.2011.586995.

23. Munneke G.A. Legal Skills for a Transforming Profession. Pace University School of Law. Vol. 22. 2001. URL: http://digitalcommons.pace.edu/plr/vol22/iss1/3 (Last accessed: 03.09.2019).

24. Seize the Future: Forecasting and Influencing the Future of the Legal Profession / Edited by G.A. Munneke. American Bar Association. Section of Law Practice Management. 2000.

25. Shuy W.R. Linguistics in the courtroom: a practical guide. Oxford University Press. Inc. New York. The USA. 2006.

26. Solam L.A., Ainsworth J., Shuy R.W. Speaking of Language and Law / Edited by Lawrence M. Solan, Janet Ainsworth, and Roger W. Shuy. Oxford University Press. Oxford. UK. 2015.

27. Tiersma P. Legal English. University of Chicago Press. The USA. 1999.

28. Wilson K. Critical reading, critical thinking: Delicate scaffolding in English for Academic Purposes (EAP). Thinking Skills and Creativity. 2016. P. 256. DOI: 10.1016/j.tsc.2016.10.002.

29. Wyatt R. Property. Check you English Vocabulary for Law, A\&C Black. London. 2006. Pp. 52-53.

30. Wydick R.C. Plain English for Lawyers. California Law Review. Vol. 66. 1978. Pp. 7-31. DOI: 10.15779/Z38T44G.

31. Zhabotynska S.A. Principles of building conceptual models for thesaurus dictionaries. Cognition, communication, discourse. International On-line Journal. 2010. 1. Pp. 72-92. DOI: 10.26565/2218-2926-2010-01-0. URL: http://sites.google.com/site/cognitiondiscourse/vypusk-no1-2010 (Last accessed: 30.01.2019).

32. Živković S. A Model of Critical Thinking as an Important Attribute for Success in the 21st Century. Procedia - Social and Behavioral Sciences. Vol. 232. 2016. Pp. 102-108. DOI: 10.1016/j.sbspro.2016.10.034.

Information about the author: Dunaievska O. V.,

Candidate of Philological Sciences, Associate Professor at the Department of Foreign Languages Taras Shevchenko National University of Kyiv 64/13, Volodymyrska str., Kyiv, 01601, Ukraine 